Dialectologia 17 (2016), 151-166.

ISSN: 2013-2247

Received 17 September 2014.

Accepted 11 January 2015.

\title{
THE REGISTER OF GAMES:
}

\section{A STUDY OF THE LANGUAGES OF THE GAMES IN INDIA}

\author{
Amitabh VIKRAM DWIVEDI \\ Shri Mata Vaishno Devi University* \\ amitabhvikram@yahoo.co.in
}

Abstract

This paper is a study of the register (a variety of a language used for a particular purpose for a particular setting) of various games commonly played by children in India. The study will take into account the language of six games (three played by girls and three by boys in teenage years) for linguistic analysis in the study. The registers of the games include rhyme-scheme for the specific game, and the words associated with the games. The two genders quite vary in their languages of games. The study will find out the reflection of their sexes in the registers employed by them.

This socio-linguistic analysis will analyze the field data by examining speech practices associated with gender, and studying self-disclosure, and politeness theory in these games. The data will be observed in Hindi language (one of the official languages of India spoken in Northern India) and transcribed in International Phonetic Alphabets along with liner translation in English.

\section{Keywords}

Games, register, linguistic analysis, self-disclosure, politeness theory

\footnotetext{
* Department of Languages \& Literature, Shri Mata Vaishno Devi University, Kakrayal, Jammu \& Kashmir,
} INDIA 182320. 
EL REGISTRO DE LOS JUEGOS:

\section{UN ESTUDIO SOBRE LA LENGUA UTILIZADA EN LOS JUEGOS EN LA INDIA}

\section{Resumen}

Este trabajo es un estudio sobre el registro (una variedad de la lengua utilizada para un propósito particular en un contexto particular) utilizado en varios juegos jugados comúnmente por niños en la India. El estudio se analizará la lengua usada en seis juegos (tres jugados por niñas y tres por niños adolescentes). Los registros de los juegos incluyen el esquema rítmico para un juego específico y las palabras asociadas a los juegos. El género es una variable relevante en el estudio lingüístico de los juegos. Este estudio pretende describir cómo el género condiciona el registro utilizado en los juegos.

Este análisis sociolingüístico analizará los datos obtenidos mediante el examen de muestras de habla asociadas con el género, y estudiará, en los juegos, los mecanismos de autorevelación personal y teoría de la cortesía que se usan. Los datos se han recogido en lengua hindi (una de las lenguas oficiales de la India hablada en el norte) y se transcribirán fonéticamente junto con la correspondiente traducción al inglés.

\section{Palabras clave}

juego, registro, análisis lingüístico, autorevelación personal, teoría de la cortesía

\section{Introduction}

This paper is a study of the language of games commonly played by children in India. The paper will take into account the registers of various games played by both the genders. The emphasis is on children's verbal expressions in Hindi language, including rhyme-schemes, word association and selection, and other linguistic devises employed by children during the play. The focus of this work is to study the registers employed by children. This socio-linguistic analysis will analyze the data through employing ethnographic approach by examining speech practices and self-disclosure associated in these games. The data for this paper has been observed in Hindi language (an official language in India), and it has been written using Roman alphabet along with liner translation in English.

This paper finds its motivation from UNESCO's initiative to empower girls, women, and children through physical education and sport. UNESCO is presently creating an International Network on Traditional Sports and Games (TSG), and this database will be 
set up with information about the main actors in traditional sports and games across the globe. The objective of this paper is to promote Indian traditional games while discussing the linguistic issues in them.

The remainder of this paper is organized under the following headings: Value of Traditional Games tells about the significance of traditional games in India, the heading Indian Games recounts some of the popular games of India, under the Theoretical foundation a brief account of previous studies conducted in games is presented, in the next section Data and discussion, the data is discussed employing cultural-historical perspective; it is supported by the content analysis, and finally the heading Conclusion concludes the paper.

\section{Value of Traditional Games}

When we watch today's children playing football, volleyball, badminton, tennis, cricket, hockey, video games, etc. we can trace a difference between the two generations of India-the previous generation (in 1980s and before) used to play traditional Indian games while the present generation is forgetting them. Nobody is playing games, such as Vish-Amrit ('Poison-Nectar'), Kabaddi, Gulli Danda ('Bail-Stick'), Asta-Changa-Pay ('Eight-Four-One'), Kanche ('Marbles'), Maar-Dhaar ('Hit and Run'), Satolia ('Seven Round Stones') and other traditional games in India. These games used to pass culture, heritage and traditional knowledge from one generation to another. The traditional games were designed not only to strengthen hand and eye coordination but they were structured in such a manner to assist learning which is required for multidimensional development, such as concentration, strategic building, logical thinking, mutual coordination, aiming, and other physical involvements. These games used to cater an overall development of children for that present day parents are paying fees to personal development centers. Indian games-indoor and outdoor-are too based on the competition in which either you win or lose, or sometimes it is a draw. Each game, besides providing fun and entertainment, also develops sensory and motor skills of the participant. Most of the traditional games are environment friendly, and they can be 
played in small spaces in the vicinity. They are for all generations, and suitable for all ages.

\begin{tabular}{l|l|l}
\hline \multicolumn{1}{c|}{ Categories } & \multicolumn{1}{c}{ Modern Indian Games } & Traditional Indian Games \\
\hline 1. Space & Require more space & Require less space \\
\hline 2. Location & Fixed & Not fixed \\
\hline 3. Cost & High & Low \\
\hline 4. Equipments/tools, etc. & Branded products often costly & Easily accessible at low prize \\
\hline 5. Human Resource & More & Less \\
\hline 6. Gender Restriction & No & Yes \\
\hline 7. Mixing of age group & Partially allowed & Allowed \\
\hline 8. Register of games & Uniform and conform to international & Social and regional variations \\
& standard, not open to changes & $\begin{array}{l}\text { are available, it is open to } \\
\text { changes }\end{array}$ \\
\hline 9. Goal & Played for competition and winning & Played for pleasure \\
\hline 10. Time & Require more time to play a game & Less time \\
\hline
\end{tabular}

Table 1. Modern Indian Games vs. Traditional Indian Games

\section{Traditional Indian Games}

India has a wonderful tradition of games which can be played by both amateur and skilled players. These games are varied from Indoor games, Outdoor games, Board games, and Property games, Language games to games based on marriage or traditional rites and rituals. North Indian games in Hindi language are different from the rest of states of the Republic of India linguistically; and they also represent festivals, social institutions, and folkloric traditions. Following are some of the traditional Indian games:

1. Patang Baji 'Kite flying': Children fly colorful kites with the abrasive strings. They compete with each other by cutting the competitors' kites. The register which is associated with the game is: manja 'abrasive strings', girgiri 'a tool on which stings are coiled', sheh 'to provide excessive stings to kite', khech 'to pull the strings', khechamtani 'competing to capture the competitors' kite while pulling', duggi 'small kite', dagga 'big kite', kata he-kata he 'an expression in vocative case when you cut the strings of the competitor's kite', etc. 
2. Gilli Danda 'bail-stick': The players hit bail with the stick. The farther your bail goes the more you score. If the competitor catches bail, or hits the stick with bail then rival is out. The register which is associated with the game is: gicchi 'a two inches hole in the round to place the bail', dand 'penalty', etc. Two or more than two players can play the game either single or in team.

3. Kanche 'Marbles': The glass marbles come in various colors and sizes. The players throw the marble on the ground, and he/she beats the selected marble from the opponent's choice. If you hit the target then you win otherwise you lose. The register which is associated with the game is: gicchi 'a two inches hole in the round to place the bail', dand 'penalty', etc.

4. Satolia 'Seven Round Stone': The players make a pile of flat stones in round shape. They try to knock them down with the rubber or plastic ball. While a player try to pile up and arrange the knocked off stones again, the opponents try to hit the player with the ball. If the ball touches you then you are out. If you succeed to arrange all the seven stones set in a sequence then you are a winner. The register which is associated with this game is: satolia 'I made the set', wo maaraa 'I hit/out.', etc.

5. Langadi Taang 'Hopping': The player throws a round stone in a box, and then hops on one leg in the boxes and pick up the stone without touching the boundary of the square box. The player needs to jumps over the box where the stone lies. Whoever does this for 1-10 boxes is the winner.

6. Latto 'Pointed Top': The players try to spin their tops as long as possible. They make a target of the opponent's top and cleave it into two. The winner is whose top spins for longer duration and cleaves the largest number of tops.

These are a few representative traditional games of India. The next section throws light on the theoretical perspective of games. The section data and discussion further discusses language games in details along with the register of other physical games. 


\section{Theoretical Foundations}

Play, game or sport has been defined by researchers and scholars in many ways. Their criteria vary according to the purpose of their needs. But a common factor across various theoretical representations to define anything as a play, game or sport if it is an engaging and demanding activity, and it is accomplished for its own sake. The register of games is generally an uncensored activity which represents the players' spontaneous ideas created for the sake of fun. The rhyme scheme of any game is largely motivated by this function only. Freud et al. (1900) gives emphasis on the function of conflictprocessing in a play. He focuses on the tension-releasing and discharging emotional elements inherently imbibed in a play which provide pleasure to a player. He states that in a play children practice the same experience repeatedly, and they gradually master it. With this self-healing process as emphasized by Freud, Children also participate in social and societal activities. Erikson (1964) believes that child develops an ability to control reality through experiments and planning during the play. He maintains a chronology based of various types of sports and how they are conducive for the development of the child.

Play is important for the cognitive development of the child. Piaget (1959) and Vygotskiĭ et al. (1987) consider play as a positive and leading activity respectively. Piaget states that a play helps to build emotional and intellectual equilibrium of a child where as Vygotskii believes that a child is always ahead of its age and normal behavior in a play. It becomes a gateway to the Zone of Proximal Development (ZPD) for children. Classical thinkers and researchers on play postulate that it is a beneficial activity, and not only children but adults also participate and engage themselves in both rational and irrational games.

Researchers have been studying various interdependent levels-individual, group, social, societal, and historical-where human play activity occurs. Schousboe $\&$ WintherLindqvist (2013) make a subtle distinction between play and playfulness with reference to the actual activity of playing and player's wish to participate in the play. Any wish to participate may in turn become an unpleasant experience for the player, and many play itself can be described an unattractive experience of playfulness. In this study, however, 
the focus is on pleasant experience through voluntary engagement and participation as the data is from the children's game only. This study is supported by cultural-historical perspectives given by Schousboe and Lindqvist (2013) which purport that "the development of human beings is entangled with the developments in the surroundings they live in."

\section{Data and Discussion}

The data ${ }^{1}$ of this paper for language games had been collected from many children in schools in Rajasthan and Uttar Pradesh States of the Republic of India. For ethical reasons I am unable to name the individual members or schools of the social communities. Learning a language is the first human thing that children do, and probably every normal human being masters a language in his/her initial three years of life. If we examine this learning/acquisition process we will find that there are grammatical rules and appropriateness constraint in this problem-solving/languagelearning game. The registers of games that children play at later stages are assisted by the language that they acquired earlier. Moreover, cognitive games, such as riddles, ludling (secret language) or argot, and others employ language more actively than the physical and social games.

The common ludling or argot which Hindi speaking children play quite often is known as gupt/chor bhasha 'secret language.' The derivation of words is simple; it adds NC (nasal-consonant) and C (voiceless affricate consonant) to already existing word's initial syllable. It copies a vowel from the initial syllable, here in the example (1) it copies a long vowel $a a$ from baa and the adds it to $C$ structure, e.g.

(1) baadashah 'king' becomes baa[-n-ch(aa)-]dashah (usage in noun)

chidiyaa 'bird' becomes chi[-n-ch(i)-]diyaa 'bird' (usage in noun)

baadashah chidiyaa maartaa he 'The king kills a bird.'

king bird kill Auxiliary becomes

\footnotetext{
${ }^{1}$ My study of children's play would not have been possible without the assistance of Ms. Gargi who made contact with girls' schools and collected data for the register of games.
} 
ba[-n-ch(aa)-]dashah chi[-n-ch(i)-]diyaa maa[-n-ch(aa)-]rtaa h[-n-ch(-)-]e (usage in sentence)

The round brackets show the copied vowel.

There is no one satisfactory answers to the question why do children need to develop a secret language for themselves, and what pleasure do they get in it? This language game is obviously not for winning or losing but for creating a secret community among themselves. ${ }^{2}$ But the examples clearly justify that the register of games is different from the ordinary language, and it can be coined anytime depending upon the requirement of the player. Moreover, a game may transfer from one generation to another but as human language evolves similarly the register of a language also changes. The language play by children has been of interest to psychologists and researchers. Thomas (2007) in his study points out the "carnivalesque" nature of such creativity of speech. He says that this language is probably structured by the children to undermine authorities and conventions, and employed by them out of the earshot from their parents, teachers, and other governing bodies. This creative aspect of language used by children also specify an important principle of language learning that people who communicate do not listen to each sound and word but their focus remain on the meaning instead. Moreover, the ludling does not alter the periphery of the word, and the changes occur only in the middle syllable of the word. Vygotskil et al. (1987) states that such devices are important for appropriating meta-linguistic abilities and skills of reading and writing. He says that this ability makes the language forms opaque, and they attend to them in and for themselves. Riddle is another language-based game. It includes various literary devices, such as alliterations, rhyme-scheme, similes, metaphors, non-sense verse, etc.

Nonsense verse often includes nonsense word (NW), parody, highly rhythmic nature of words, words which are censored, tongue twisters, and dirty jokes. They cannot be defined as a game as such in terms of winning and losing but these language

\footnotetext{
${ }^{2}$ Since I also used this ludling in my childhood (6-7 years old), I can say that a desire to say something which only a restricted group can understand motivated me.
} 
plays are popular among children and they generate playfulness. One such game is to find out who has fart in the group. Anyone from the group starts singing the nonsense rhyme pointing at each one after uttering each word, and the culprit is the one on which the final word dhoos 'an onomatopoeic word for farting' ends, e.g.

$\begin{array}{lllll}\text { (2) } \operatorname{aad}(\mathrm{aa}) & \operatorname{paad}(\mathrm{aa}) & \text { kaun } & \operatorname{paad}(\mathrm{aa}) & \text { (line 1) (aa) rhyming } \\ (\mathrm{NW}) & \text { fart } & \text { who } & \text { fart } & \end{array}$

$\begin{array}{lllll}\text { raam-ji } & \text { kaa } & \operatorname{ghod}(\mathrm{aa}) & \operatorname{paad}(\mathrm{aa}) & \text { (line 2) (aa) rhyming } \\ \text { God Ram } & \text { of } & \text { horse } & \text { fart } & \end{array}$

aai mai dhoos

(NW) (NW) 'an onomatopoeic word for farting'

Seemingly explicit sexual overtone in general interrogative discourse marker and its reply is in fact only a rhyme scheme to generate fun for children, e.g.

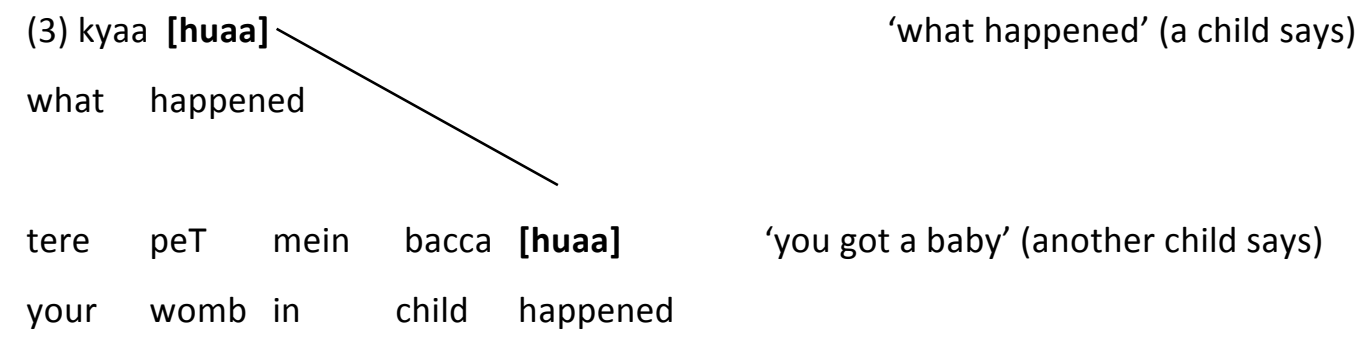

Children also employ pun in their day-to-day language. Masti 'mischief/condom brand' is an ambiguous word, and children use it as a pun in the following example:
(4) masti
mat kar
'Don't do mischief.' (a child says)
mischief/Condom brand
not do
mein to
Kohinoor/Moods
kar raha hoon 'I am using Moods/Kohinoor.'
I EMP marker Condom brands
doing am (another one replies) 
Similarly, Kathryn Marsh (2008) recorded in her study that a group of children from Years 2 and 3 at Springfield Primary School were playing a song which was about "having sex and having a baby" without knowing the actual meaning of rhyme scheme.

Sutton-Smith's (1997) studies on play have had a significant impact on researches in play. His focus was on every conceivable perspective associated with the play. He emphasizes that play can become a delightful as well as a rude experience for the players, and they sometimes establish social order and at times violate it. Ludlings, dirty jokes, and other language games conform to this notion. Most of the language games might sound irrational and silly to the established notions of adults for games, but this initial confrontation posed by the logical/rational supporters of games can be pacified by the United Nations declaration about children's rights to play games is a human right for children. At the same time researchers and social thinkers are also concerned about the harmful impact of Modern games, such as video games, fighting games, war games, and others which are largely motivated by violent and sexual imagery. Furthermore, the addiction for modern technological games also encourages the parents and others to gear up for the traditional games.

It is not the case that elaborate rhyming scheme is only associated with language games. Multiple rhyme schemes linked with physical games explains talking-whileplaying phenomenon with traditional games. In traditional games a complex elaborate musical construction juxtaposes with the game. These musical plays involve rhythmic language, movements, and text, e.g. a rhyme scheme associated with Kanche 'Marbles' goes like this:

\begin{tabular}{|c|c|c|c|c|}
\hline ikkal & \multicolumn{2}{|l|}{ gaanjaa } & $a$ & (line 1 ) \\
\hline one & (NW) & & & \\
\hline dudh & pilaajaa & & $a$ & (line 2) \\
\hline milk & drink & & & \\
\hline tiin & ki & Tik Tik & b & (line 3) \\
\hline hree & of & tic-tic & & \\
\hline
\end{tabular}


Dialectologia 17 (2016), 151-166.

ISSN: 2013-2247

\begin{tabular}{|c|c|c|c|}
\hline cholam & chaaku & C & (line 4) \\
\hline four & knife & & \\
\hline paanch ka & peindu & C & (line 5) \\
\hline five of & $(N W)$ & & \\
\hline chak-mak & deindu & C & (line 6) \\
\hline $\operatorname{six} \quad(N W)$ & (NW) & & \\
\hline saat & sutii & $d$ & (line 7) \\
\hline seven of & $(\mathrm{NW})$ & & \\
\hline aaTh & uTii & $d$ & (line 8) \\
\hline eight of & (NW) & & \\
\hline nammak & naaraa & e & (line 9) \\
\hline nine & (NW) & & \\
\hline das & dhaaraa & $\mathrm{e}$ & (line 10) \\
\hline ten & stream & & \\
\hline
\end{tabular}

This game is played by two or more players. Each player throws his/her marble from a metre distance into the gicci 'an inch hole in the ground.' Whose marble is near gicci or inside it starts first. The players hit another players' marbles by making an arc with palm while putting their thumb on the ground and stretching the finger, and then gradually releases the marble. If it beats the other player's marble, the player gets the point. Any player who does this ten times first is the winner of the game. After every correct aim/hit the player sings the corresponding rhyme.

Rhythmic and formal complexity of language increases gradually from duple meter to metrical change in asymmetrical meters in their games, e.g. in a game mostly played by girls the rhyme goes: 
(6)

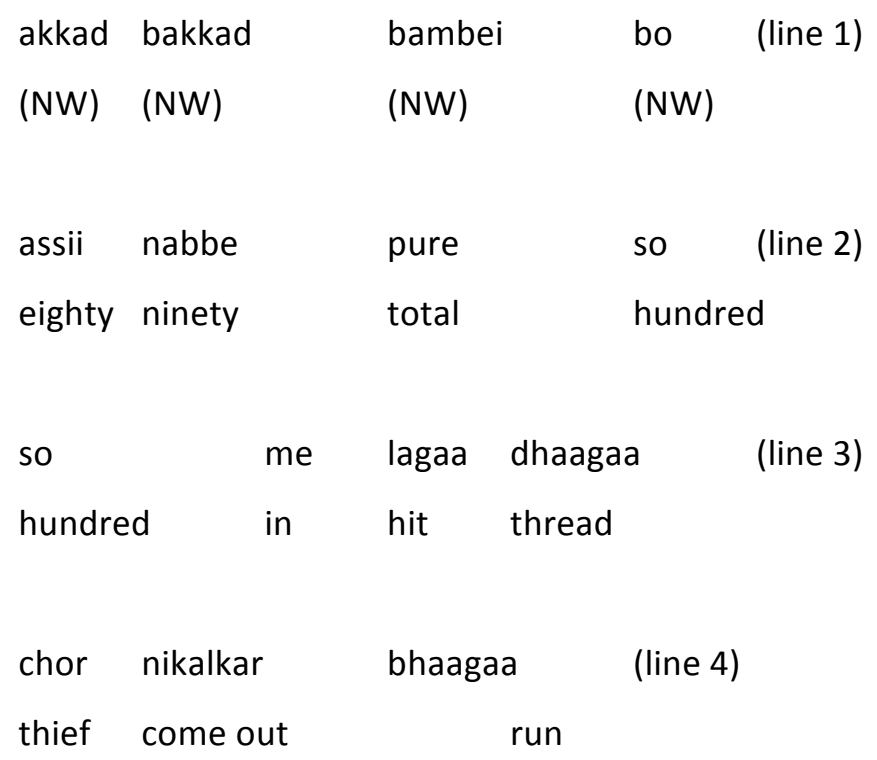

Orff and Kodaly believe that initially children do not like study (Carder \& Landis 1990). They would rather prefer to play than to learn anything. Since musical elements remain predominant in their play, Orff-Shulwerk advocates a "child-centered" playbased way of encouraging learning. Kodaly advocates that musical education is important in beginning years of formal education for children, particularly between the games of three and seven (Choksy 1981). The pedagogical implication based on these rhyming games can be observed in the tenets of educational methodology in the classroom.

\section{Conclusions}

The registers of children's traditional games are important not only in cultural tradition but it also paves a path for a musical educational tradition for learning. The important aspects of these register are that they are created by them to learn linguistic and meta-linguistic activities through games. Though most of the registers of games have been lost as the modern generation is forgetting them yet an effort like UNESCO's to create a Network on Traditional Sports and Games (TSG) will surely help to save this cultural heritage of India. This paper is also written in a similar direction to motivate the readers in the area of the registers of traditional language games. Extensive fieldwork 
Dialectologia 17 (2016), 151-166.

ISSN: 2013-2247

and data collection can save this tradition before falling into oblivion. However, further studies can be done on the variations of registers employed by the boys and girls in their games respectively.

\section{References}

CARDER, P. \& B. LANDIS (1990) The Eclectic curriculum in American music education: Contributions of Dalcroze, Kodály, and Orff, Reston, VA: Music Educators National Conference.

CHOKSY, L. (1981) The Kodaly context: Creating an environment for musical learning, Englewood Cliffs, N.J: Prentice-Hall.

ERIKson, E. H. (1964) Childhood and society, New York: Norton.

Freud, S., J. Strachey, A. Freud, A. Richards \& Scientific literature Corporation (1900) The standard edition of the complete psychological works of Sigmund Freud, London: Hogarth Press.

Indian TRAditional Games (n.d.) Retrieved from http://www.traditionalgames.in/ (27 August 2014).

MARSH, K. (2008) The musical playground: Global tradition and change in children's songs and games, Oxford: Oxford University Press.

PIAGET, J. (1959) The language and thought of the child, New York: Humanities Press.

SCHOUSBOE, I. \& D. WINTHER-LINDQVIST (2013) Children's play and development: Cultural-historical perspectives, Dordrecht: Springer.

$\begin{array}{llllll}\text { SOVIET } & \text { PSYCHOLOG: } & \text { PLAY } & \text { (n.d.) } & \text { Retrieved }\end{array}$ https://www.marxists.org/archive/vygotsky/works/1933/play.htm (19 July 2014).

SUtTON-SMITH, B. (1997) The ambiguity of play, Cambridge, Mass: Harvard University Press.

THOMAS, J. T. (2007) Poetry's playground: The culture of contemporary American children's poetry, Detroit: Wayne State University Press.

United NATIONS GIRLS' EdUCATION INITIATIVE (n. d.) Retrieved from http://www.ungei.org/index.php (20 August 2014).

UNESCO's Network on Traditional Sports and Games (TSG) | United nations Educational, Scientific and Cultural Organization (n. d.) Retrieved from http://www.unesco.org/new/en/social-and-human-sciences/themes/physical-education- 
and-sport/traditional-sports-and-games/unescos-network-on-traditional-sports-andgames-tsg/ (20 August 2014).

Vygotskĭ, L. S., R. W. Rieber, A. S. CARton, N. Minick, L. S. Vygotskĭ \& L. Vygotsky (1987) The collected works of L.S. Vygotsky, vol. 1, New York: Plenum. 


\section{Appendix}

Major traditional Indian Games

\begin{tabular}{|c|c|}
\hline Games & Description \\
\hline $\begin{array}{l}\text { 1. Patang Baji 'Kite } \\
\text { flying' }\end{array}$ & $\begin{array}{l}\text { Children fly colorful kites with the abrasive strings. They compete with } \\
\text { each other by cutting the competitors' kites. The register which is } \\
\text { associated with the game is: manja 'abrasive strings', girgiri 'a tool on } \\
\text { which stings are coiled', sheh 'to provide excessive stings to kite', khech 'to } \\
\text { pull the strings', khecham-tani 'competing to capture the competitors' kite } \\
\text { while pulling', duggi 'small kite', dagga 'big kite', kata he-kata he 'an } \\
\text { expression in vocative case when you cut the strings of the competitor's } \\
\text { kite', etc. }\end{array}$ \\
\hline $\begin{array}{l}\text { 2. Gilli Danda 'bail- } \\
\text { stick' }\end{array}$ & $\begin{array}{l}\text { The players hit bail with the stick. The farther your bail goes the more you } \\
\text { score. If the competitor catches bail, or hits the stick with bail then rival is } \\
\text { out. The register which is associated with the game is: gicchi 'a two inches } \\
\text { hole in the round to place the bail', dand 'penalty', etc. Two or more than } \\
\text { two players can play the game either single or in team. }\end{array}$ \\
\hline $\begin{array}{l}\text { 3. Kanche } \\
\text { 'Marbles' }\end{array}$ & $\begin{array}{l}\text { The glass marbles come in various colors and sizes. The players throw the } \\
\text { marble on the ground, and he/she beats the selected marble from the } \\
\text { opponent's choice. If you hit the target then you win otherwise you lose. } \\
\text { The register which is associated with the game is: gicchi 'a two inches hole } \\
\text { in the round to place the bail', dand 'penalty', etc. }\end{array}$ \\
\hline $\begin{array}{l}\text { 4. Satolia 'Seven } \\
\text { Round Stone' }\end{array}$ & $\begin{array}{l}\text { The players make a pile of flat stones in round shape. They try to knock } \\
\text { them down with the rubber or plastic ball. While a player try to pile up }\end{array}$ \\
\hline
\end{tabular}




\begin{tabular}{|c|c|}
\hline & $\begin{array}{l}\text { and arrange the knocked off stones again, the opponents try to hit the } \\
\text { player with the ball. If the ball touches you then you are out. If you } \\
\text { succeed to arrange all the seven stones set in a sequence then you are a } \\
\text { winner. The register which is associated with this game is: satolia 'I made } \\
\text { the set.', wo maaraa 'I hit.', etc. }\end{array}$ \\
\hline $\begin{array}{l}\text { 5. Langadi Taang } \\
\text { 'Hopping' }\end{array}$ & $\begin{array}{l}\text { The player throws a round stone in a box, and then hops on one leg in the } \\
\text { boxes and pick up the stone without touching the boundary of the square } \\
\text { box. The player needs to jumps over the box where the stone lies. } \\
\text { Whoever does this for } 1-10 \text { boxes is the winner. }\end{array}$ \\
\hline $\begin{array}{l}\text { 6. Latto 'Pointed } \\
\text { Top' }\end{array}$ & $\begin{array}{l}\text { The players try to spin their tops as long as possible. They make a target of } \\
\text { the opponent's top and cleave it into two. The winner is whose top spins } \\
\text { for longer duration and cleaves the largest number of tops. }\end{array}$ \\
\hline
\end{tabular}

